any solution that is offered, if it is to be carried into practice, will ultimately rest upon the favor of the several state boards and their willingness to co-operate. Very probably additional legislation may be required in order to give them the power of discriminating, so as to recognize the distinction between the two classes of candidates: 1 , those who are required to demonstrate their fitness for the responsibilities of medical practice and, 2, those about whose fitness there is no question whatever. As a means of affording presentrelief to the members of the latter class, the writer would make the suggestion that the state medical societies might consent to co-operate with the examining boards. For instance, if a reputable member of the profession, who has been actively engaged in practice, for, say, ten years, desires to change his field of work he can apply for a certificate from his state medical society, which could be endorsed by the medical society of the state to which he is going. Such evidence of professional attainments might well be accepted by the examining board of the state concerned, and thus aid in carrying out the idea of interstate comity or reciprocity, while recognizing and upholding the dignity of the profession. Very respectfully yours,

Frank Woodbury.

\section{A Voluntary Board Will Not Accomplish the Result Desired.}

NEw Yoris, May 17, 1902.

To the Editor:-I have read with great interest the article of Dr. Rodman in the issue of THE Jourat of the 10th inst. and your very able editorial on the same. You having invited a free expression of opinion pro and con, I take the liberty to analyze it and point out wherein I differ. The evil that this voluntary board of national examiners is expected to remedy is supposed to be this: that a graduate of a medical college of high standard, holding a certificate from a state board, is compelled to pass an examination in case of his removal to another state.

Will this proposed board accomplish the result? Any state which demands an examination from one possessing credentials of registration in a state with a high medical standard, will also refuse to recognize a license of a national voluntary board; as a matter of fact the multitude of examinations we are blessed with in this country are for the purpose of barring a brother practitioner from locating in that state.

Were it not for that, what excuse is there to demand an examination from a physician who has registered and was allowed to practice? It is un-American as well as unjust. Where is the fair play we Americans are proud of?

Your editorial admits that, should the volunteer national board be realized and all the states consent to relinquish their rights to the national board, this would only assist those that would pass the examination of the board, and no relief is suggested to the thousands of physicians who are in practice. What should the practitioner do who is unfortunate, and on account of sickness is compelled to change climate? The young man can take care of himself, he can pass an examination wherever he goes, but the older man, though he may be rusty on technical points, is far advanced on practical points, and to him the doors are closed. It is ridiculous that a man who was good enough for the community of one state should not be allowed to practice in another state.

What is the remedy for the multiple examinations of every state? The Association should put itself on record that every state which comes up to the standard should reciprocate, in other words, every licensed physician, whether he has passed a state examination or was exempt from it by reason of previous registration, should be allowed to register on the presentation of proper credentials, on paying the fee according to law.

We ought to be honest about it. When a physician is good enough, in a state that comes up to the standard, why should he be rejected by another state? The objection that the man who registered before the law passed does not come up to the standard is not well taken, because he has the advantage of experience instead. Some of the best teachers have never passed a state examination and some were even students of a two-year course. Their constant work and perseverance in study after graduation, combined with experience, raised them far above the average. Dr. Rodman further states: "The Com" mittee on National Legislation, representing the A. M. A., has reported, advising against reciprocity and in favor of a national board of examiners. The committee had, however, been working upon the hypothesis that such a board could be created and sustained by act of Congress. Letters read from

caused the committee to drop the idea of a national board created by act of Congress as such legislation would certainly be unconstitutional and in conflict with the several states. The states are sovereign and can not be coerced by the general government." A national board would be for the benefit of the community against impostors, and every state which is mindful of the common welfare would come under its folds sooner or later by its own free will. There would be no objection to a national board when accepted by a voluntary relinquishment of rights on the part of the state. But such a board must first have the stamp of the country at large, by an act of Congress, which would give it the high standiing and reputation to gain the respect of the whole nation, as well as of foreign countries. The high standing of the surgeons-general of the Army, Navy and Marine-Hospital Service is not so much on account of their superior knowledge as it is on account of their position representing the national government. If such a board were made national it would then compare with the Royal College of Physicians.

I would suggest that a national body be created by Congress, to be called "The Commission of Health of the United States," with headquarters in Washington, to have supervision over all medical matters of the United States, such as the granting of certificates to candidates after successful examinations, which should suftice for the medical departments of the Army, Navy and Marine-Hospital Service, and for any state or territory which by consent relinquished its state authority. This commission should supervise the manufacture of drugs, chemicals, serum, etc. This commission should not interfere in commerce, acting only when requested by the manufacturer to examine his goods, and if they be found to be up to a standard, to issue a certificate to that effect. The members of the commission should consist of the surgeons-general of the Army, Navy and Marine-Hospital, and one member for every state, to be elected by the American Medical Association, yearly, of such states that consent to relinquish their state authority to the commission. And this commission should have a salaried officer to be in charge all the time with salaried assistants to carry on the duties of his office. Very truly yours,

1085 Lexington Avenue, New York City.

\section{W. ZwISOHN.}

\section{A Broader National Examining Board.}

JefHerson Cuty, Mo., May 15, 1902.

To the Journal:-The medical profession has not been altogether wise in its efforts for state regulation of the medical art. In the very eager pursuit of the charlatan the dignified and careworn family physician was almost forgotten. Under the medical laws of the several states he has less freedom of movement than the plumber or the iron molder. Physicians do not always change location for a moneyed consideration, but oftentimes to engage in special work, or to lighten their labor, as the means of a longer and more comfortable life. We alone are responsible for the unfortunate condition, and we must apply the remedy. If the American Medical Association decides to create a voluntary national examining board, let it be on broader lines than suggested by Dr. Rodman of Philadelphia. Let us at least anticipate applicants for examination from Chicago, St. Louis, Louisville and San Francisco. And let it further be hoped that there will be recognition of state licenses already issued to physicians who have passed satisfactory examinations before state examining boards. We have physicians of great merit in all the states, and if the American Medical Association takes action in this matter at all, it must be upon the basis of intcllectual equality of the profession in all the states. I do not think the state boards will consent to a 